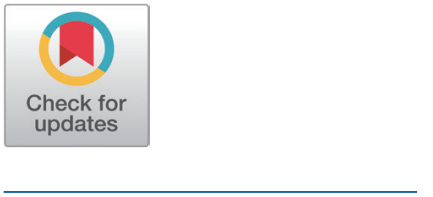

Received: Sep 8, 2021

Revised: Nov 4, 2021

Accepted: Nov 4, 2021

*Corresponding author

Barbara Anne Murphy

School of Agriculture and Food

Science, University College Dublin,

Belfield, Dublin 4, Ireland.

Tel: +353-01-716-7717

E-mail: barbara.murphy@ucd.ie

Minjung Yoon

Department of Horse, Companion and Wild Animal Science, Kyungpook National University, Sangju 37224, Korea.

Tel: +82-54-530-1233

E-mail: mjyoonemail@gmail.com

Copyright $(\subset) 2022$ Korean Society of Animal Sciences and Technology. This is an Open Access article distributed under the terms of the Creative Commons Attribution Non-Commercial License (http:// creativecommons.org/licenses/bync/4.0/) which permits unrestricted non-commercial use, distribution, and reproduction in any medium, provided the original work is properly cited.

ORCID

Seongmin Kim

https://orcid.org/0000-0002-9472-9219 Heejun Jung

https://orcid.org/0000-0001-9608-1412

Barbara Anne Murphy

https://orcid.org/0000-0003-2163-7927

Minjung Yoon

https://orcid.org/0000-0001-9112-1796

\section{Efficiency of Equilume light mask on the resumption of early estrous cyclicity and ovulation in Thoroughbred mares}

\author{
Seongmin $\mathrm{Kim}^{1}$, Heejun Jung ${ }^{1}$, Barbara Anne Murphy ${ }^{2 *}$ and Minjung Yoon ${ }^{1,3,4 *}$ \\ ${ }^{1}$ Department of Animal Science and Biotechnology, Kyungpook National University, Sangju 37224, Korea \\ ${ }^{2}$ School of Agriculture and Food Science, University College Dublin, Belfield, Dublin 4, Ireland \\ ${ }^{3}$ Department of Horse, Companion and Wild Animal Science, Kyungpook National University, Sangju \\ 37224 , Korea \\ ${ }^{4}$ Research Center for Horse Industry, Kyungpook National University, Sangju 37224, Korea
}

\section{Abstract}

Equilume light masks had no impact on hastening the resumption of estrous cyclicity in mares maintained in outdoor pastures on the mainland of Korea due to the cold weather conditions. Jeju Island is a major horse-breeding site in Korea and is warmer than the mainland during the winter season. Therefore, the primary objective of this study was to explore the efficiency of the Equilume light mask on the resumption of seasonal estrous cycles in Thoroughbred mares on Jeju Island. A total of 20 nonpregnant mares were randomly divided into the Equilume light mask $(n=9)$ and stable lighting $(n=11)$ groups. The experiment was performed at seven different horse-breeding farms located on Jeju Island from November 15,2020 , to February 15,2021 . The mares were exposed to the respective lights from 16:00 to 23:00. Follicle size and uterine edema were measured by ultrasound scanning. Body condition scores (BCS) were also monitored during the experiment. Statistical analysis was conducted using the SAS and SPSS software, and $p$-values of $<0.05$ were considered statistically significant. Two of the nine $(22.2 \%)$ mares in the Equilume light mask group and three of the $11(27.28 \%)$ mares in the stable lighting group were still cycling in December and January, which were considered as all-year-round cycling mares. On February 15, there was no difference between groups in the resumption of early seasonal estrus cycle, which was determined by follicles $>25 \mathrm{~mm}$ in addition to uterine edema. All mares in the Equilume light mask group and five of the eight mares $(62.5 \%)$ in the stable lighting group had resumed cycling. Interestingly, six of the seven mares $(87.5 \%)$ in the Equilume light mask and four of eight mares $(50 \%)$ in the stable lighting group had already ovulated on February $15(p>0.05)$, as determined by the presence of a recent corpus luteum. No difference was observed in $\mathrm{BCS}$ and uterine edema between groups $(p>0.05)$. In conclusion, the Equilume light mask can be an effective approach to induce early seasonal estrus cycles of mares in Jeju Island, and it also enhances the efficiency of farm management by reducing labor.

Keywords: Blue light, Light mask, Reproduction, Early seasonal estrus cycle, Mare, Welfare 
Competing interests

Barbara A. Murphy is the Founder of

Equilume Ltd, a spin-out company deriving from her research program as assistant professor at UCD and is a member of the company's Board of Directors. Dr. Murphy is a shareholder in Equilume Ltd. The light mask used in the presented study is a commercially available product with the following patents: AU2016231515, GB2504244, GB2549682, HK1245690, US9,839,791, US10,926,101.

Funding sources

Not applicable.

Acknowledgements

The authors would like to thank Jongbok Choi (Veterinarian, Good day animal hospital, Jeju Island) for the assistance with transrectal ultrasonography.

Availability of data and material Upon reasonable request, the datasets of this study can be available from the corresponding author.

Authors' contributions

Conceptualization: Kim S.

Data curation: Kim S.

Formal analysis: Kim S.

Methodology: Kim S, Jung H, Murphy BA Yoon M.

Writing - original draft: Kim S.

Writing - review \& editing: Kim S, Jung $\mathrm{H}$, Murphy BA,Yoon M.

Ethics approval and consent to participate All procedures in this study were approved by the Animal Experiment Ethics Committee of Kyungpook National University (permit number: 2020-0119-1)

\section{INTRODUCTION}

Horses are long-day seasonal breeding animals. During winter, $85 \%$ of Thoroughbred mares cease normal cyclic activity and enter an anestrous period [1,2]. In mares, the circannual rhythm of reproduction is primarily regulated by photoperiodic changes, with the increase in day length preceding the onset of the breeding season [3,4]. It is well documented external factor that influences the circannual rhythm $[5,6]$.

During the anestrous period, mares typically exhibit minimal-to-moderate follicular growth and an absence of periodic ovulation as a consequence of lower gonadotropin secretion [7]. Melatonin is one of the primary mediators in the regulation of gonadotropin-releasing hormone $(\mathrm{GnRH})$ secretion [8]. In mares, melatonin is synthesized and secreted by the pineal gland and its concentrations are strongly associated with the dark phase $[9,10]$. Melatonin secretion increases at the beginning of the dark phase and decreases rapidly at the end of the night [11]. During winter anestrus, the extended melatonin secretion during long periods of darkness has an inhibitory effect on $\mathrm{GnRH}$ secretion, which causes a reduction in the secretion of gonadotropin, luteinizing hormone (LH), and follicle-stimulating hormone (FSH) [12]. During the spring, increasing day lengths causes a shortening in the duration of melatonin secretion [13], releasing its inhibitory effects on $\mathrm{GnRH}$ neurons and permitting the resumption of gonadotropin secretion and the restoration of cyclic ovarian activity [14].

Understanding seasonality and the mechanisms of hormonal interplay of mares has become important for the development of methods to advance the onset of seasonal breeding in the Thoroughbred breeding industry. This is important because the annual earnings from foals born in January and February are higher than those from foals born from March to June, thus influencing the economic benefits for horse breeders $[15,16]$. Therefore several clinical treatment, including the provision of artificial photoperiod, have been implemented in the industry to advance the estrous cycle of mares [8].

The majority of these treatments have focused on increasing the photoperiod, and it has been repeatedly demonstrated that an artificial, long-day photoperiod consisting of 16 hours of light and 8 hours of dark effectively advances the time of the first ovulation in mares [17]. Clinically, various administrations such as recombinant equine FSH [18], progesterone [19], gonadotropin [20], dopamine antagonists [21], GnRH [22], and pituitary extracts [23] are used to stimulate an early onset of reproductive activity.

To remediate some inefficiencies of delivering artificial photoperiod and avoid the adverse effects associated with clinical drug administration, Equilume light masks have been developed. These masks consist of a single headpiece, wherein a blue light is exposed to the right eye. Studies in Thoroughbred have shown that melatonin can be suppressed to daytime levels using low intensity blue light (468 nm) from light emitting diodes (LED) directed at a single eye [24] and Equilume light masks were shown to effectively advance the ovulatory season of the mare. To meet the industry requirements for early breeding, we previously conducted a study to evaluate the effectiveness of Equilume light masks in advancing seasonal reproductive activity of mares on the mainland of Korea. However, the induction of early reproductive activity in Thoroughbred mares was not observed on February 10 in this study [25]. During the study, Korea experienced very cold weather, wherein the minimum temperature was $-12.8^{\circ} \mathrm{C}$ and mares had infrequent access to pasture grazing.

Our team speculated that the extreme environmental conditions and low ambient temperatures may have influenced the failure of the early onset of the breeding season of mares in the mainland of Korea. Therefore, we conducted the present study to investigate the efficiency of the Equilume 
light mask on the resumption of seasonal estrus in Thoroughbred mares in Jeju Island, a warmer region compared with the mainland and the primary location for Thoroughbred production in Korea.

\section{MATERIALS AND METHODS}

\section{Animals}

The experiment was conducted from November 15, 2020, to February 15, 2021, at 7 different barns in Jeju Island. The temperature of the region ranged from $-1.1^{\circ} \mathrm{C}$ to $22.4^{\circ} \mathrm{C}$. A total of 20 nonpregnant Thoroughbred mares, all aged between 3 to 17 years (mean age: $10.25 \pm 1.00$ ) were used for the experiment. All mares were randomly divided into the blue light group $(n=9)$ and the stable light group $(\mathrm{n}=11)$. The mean age of mares was $6.33 \pm 1.01$ years in the blue light mask group and $13.45 \pm 0.73$ years in the stable light group. All mares were out on pasture to graze by day and were supplied ad libitum with hay and fresh water throughout the experiment.

\section{Housing and management}

The first 4 breeding farms (farms 1-2: six mares of the blue light group; farms 3-4: eight mares of the stable light group) were located (geographical coordinates: $33^{\circ} 23^{\prime} 36.384^{\prime \prime} \mathrm{N}, 126^{\circ} 16^{\prime} 0.6018^{\prime \prime}$ E) within a radius of 10 kilometers in the west of Jeju Island, and the other three farms (farm 5: three mares of the blue light group; farms 6-7: three mares in the stable light group; geographical coordinates: $33^{\circ} 21^{\prime} 1.6344^{\prime \prime} \mathrm{N}, 126^{\circ} 47^{\prime} 38.5764^{\prime \prime} \mathrm{E}$ ) were located in the east within a radius of 13 kilometers in Jeju Island. Mares treated with blue light were maintained on pasture for $24 \mathrm{~h}$ per day throughout the study period, and no additional light was provided except the blue light and the natural photoperiod. Mares in the stable lighting group were pastured by day but brought into individual stables and exposed to stable white fluorescent light from 16:00 to 23:00 daily. All mares were stabled on occasions of inclement weather such as hail and heavy snow. Temperature data were recorded using a digital thermometer, and the mean temperature was calculated with the lowest and the highest temperature of the barns and the region. The daily temperatures recorded in the farms were compared.

\section{Experimental design}

The seven owners of the seven breeding farms consented to participate in the experiment, and the information in the registry of all mares (age, parity, and foaling history) in Korea Racing Association was collected 2 weeks before the initiation of the experiment. Beginning on November 15, 2020, the blue light group of mares were fitted with Equilume light masks that deliver 50 lux of blue light $(468 \mathrm{~nm})$ to the right eye. Once activated initially at 16:00, the light mask automatically turned on at 16:00 and turned off at 23:00 each day without a requirement for battery change. On December 1,2020 , the mares in the stable light group were housed in individual stalls at night and stable light that was operated from 16:00 to 23:00 each day. Transrectal ultrasonography was conducted using a S6V Portable Digital Color Doppler Ultrasound System (Sonoscape, Shenzhen, China) for each group until the end of the study (December 28, 2020; January 20, 2021; and February 15, 2021).

\section{Body condition score}

The BCS was evaluated for all mares by the same person using the Henneke system each month throughout the study period [26]. Six body parts (neck, withers, back, tail-head, ribs, and behind the shoulders) were palpated and visualized and scored from 1 to 9 , with 1 indicating poor body condition and 9 indicating an obese body condition. 


\section{Criterion of mares' ovarian activity}

The ultrasound scans were performed by a qualified veterinarian to check for ovarian activity in terms of the size and number of follicles and the presence or absence of uterine edema and corpora lutea. Estrous cyclicity was defined as the presence of follicles measuring $\geq 25 \mathrm{~mm}$ in diameter in conjunction with uterine edema indicative of estrus. Ovulation was determined by the presence of a previously unrecorded corpus luteum. The anestrus phase was determined as ovaries with follicles measuring $<25 \mathrm{~mm}$ in diameter and with no associated physiological characteristics typical of estrous activity. The characteristics of uterine edema were graded based on the visibility on a scale of 1-3: with 1 indicating endometrial folds not visible, 2 indicating visible but indistinct endometrial folds, and 3 indicating distinct endometrial folds.

\section{Statistics}

The SAS software (SAS Institute, Cary, NC, USA) was used to perform the statistical analysis using the general repeated model for repeated measures for the body condition score and the status of uterine edema. Results are shown as mean \pm SEM. The SPSS software was used to perform to compare mean temperature between the barns using ANOVA to confirm differences in ambient temperatures between locations. Pairwise comparisons were conducted using chi-square for the statistical analyses for classification of estrus and anestrus and for the number of mares that had ovulated within each group on each date. Results are represented as the number of mares and calculated as the percentage. The level of significance was set at $p<0.05$.

\section{RESULTS}

\section{Body condition score and the uterine edema score}

The mean body condition score ranged from 4.0 to 6.0 for each group. There was no difference observed in the mean body condition score of the mares between groups. However, a difference was observed according to the time difference of each group. (Table 1). The uterine edema scores ranged between 1.0 and 2.0, with no statistical differences between the blue light group and the stable light group (Table 2).

\section{Mare reproductive status}

From December to January, in blue light treated mares, 2 mares were in estrus and 7 mares were in anestrus while in stable light treated mares, 3 mares showed estrus and 8 mares showed anestrus. 5 mares (2 from blue light and 3 from the stable light treatment group) were excluded for data analysis in February considering these mares are non-seasonal polycyclic. In February, all mares in the blue light treated group showed estrus, and 5 mares out of 8 showed estrus in the stable light treated group. The number of mares classified as being in the estrus or anestrus phase were not significantly different in December-January $(p=0.795)$ and February $(p=0.186)$. However, the number of mares showed estrus in the blue light treated group were higher than the stable light

Table 1. The mean body condition score of the mares

\begin{tabular}{llrrr}
\hline \multicolumn{1}{c}{ Group } & November & December & January & February \\
\hline Blue light $(n=9)$ & $4.94 \pm 0.10^{\mathrm{a}}$ & $5.38 \pm 0.07^{\mathrm{b}}$ & $5.5 \pm 0.08^{\mathrm{b}}$ & $5.38 \pm 0.07^{\mathrm{b}}$ \\
Stable light $(\mathrm{n}=11)$ & $5.09 \pm 0.16^{\mathrm{a}}$ & $5.4 \pm 0.06^{\mathrm{b}}$ & $5.45 \pm 0.04^{\mathrm{b}}$ & $5.36 \pm 0.07^{\mathrm{b}}$ \\
\hline
\end{tabular}

The results are expressed as the mean \pm SEM.

Different superscripts indicate statistical difference $(p<0.05)$. 
Table 2. The mean uterine edema score of the mares

\begin{tabular}{lccc}
\hline \multicolumn{1}{c}{ Group } & December & January & February \\
\hline Blue light $(n=9)$ & $1.44 \pm 0.29$ & $1.67 \pm 0.29$ & $2.11 \pm 0.30$ \\
Stable light $(n=11)$ & $1.83 \pm 0.29$ & $1.41 \pm 0.19$ & $1.63 \pm 0.24$ \\
\hline
\end{tabular}

The results are expressed as the mean \pm SEM.

treated group. (Table 3$)$.

\section{Number of ovulating mares}

Ovulation was observed in 4 out of 5 mares (both groups) in December to January but these animals were excluded in February's statistical data as mentioned earlier, keeping these mares nonseasonal polycyclic. In February, 6 out of 7 mares in the blue light treated group and 4 out of 8 mares showed ovulation in the stable light treated group. The proportion of mares that had ovulated in the blue light group and the stable light group was not significantly different in DecemberJanuary $(p=0.369)$ and February $(p=0.329)$. However, the number of ovulated mares in the blue light treated group were higher than the stable light treated group (Table 4).

\section{Temperature}

There was no significant difference in mean temperature between barns (Barn 1: $9.36^{\circ} \mathrm{C}$; Barn 2: $9.32^{\circ} \mathrm{C}$; Barn 3: $8.66^{\circ} \mathrm{C}$; Barn $4: 9.12^{\circ} \mathrm{C}$; Barn 5: $9.36^{\circ} \mathrm{C}$; Barn 6: $8.12{ }^{\circ} \mathrm{C}$; and Barn $7: 8.92^{\circ} \mathrm{C}$ ) (Fig. 1). The mean temperature of Jeju Island was $9.4^{\circ} \mathrm{C}$ (Fig. 2).

\section{DISCUSSION}

Advancement of the mare's breeding season using indoor lighting has become a standard management practice for Thoroughbred breeders. It is believed that the photoperiod is the dominant external factor that influences the mare's reproductive rhythm, and providing additional light exposure during winter stimulates ovarian activity in anestrous mares [27]. This study was conducted to evaluate the efficiency of the Equilume light mask on the resumption of early ovulation of Thoroughbred mares in Jeju Island, Korea. Our results showed that the reproductively active period of a non-pregnant mare can be advanced using blue light exposure to one eye from head-worn masks while mares are maintained at pasture and that this method is as effective as maintaining mares indoors under stable lighting. This result is consistent with a previous study that showed a resumption of early ovulation of Thoroughbred mares [28].

Table 3. Comparison of the number of mares determined to have estrus or anestrus phase

\begin{tabular}{|c|c|c|c|c|c|c|c|c|c|}
\hline Group & & December & & & January & & & February & \\
\hline Reproductive status & Estrus & Anestrus & $x^{2}(p)$ & Estrus & Anestrus & $x^{2}(p)$ & Estrus & Anestrus & $x^{2}(p)$ \\
\hline Blue light $(n=9)$ & 2 & 7 & \multirow{2}{*}{$.067(.795)$} & 2 & 7 & \multirow{2}{*}{$.067(.795)$} & 7 & 0 & \multirow{2}{*}{$3.367(.186)$} \\
\hline Stable light $(n=11)$ & 3 & 8 & & 3 & 8 & & 5 & 3 & \\
\hline
\end{tabular}

Table 4. Comparison of the number of mares determined to have ovulated

\begin{tabular}{|c|c|c|c|c|c|c|c|c|c|}
\hline Group & & December & & & January & & & February & \\
\hline Reproductive status & Ovulated & Not ovulated & $x^{2}(p)$ & Ovulated & Not ovulated & $x^{2}(p)$ & Ovulated & Not ovulated & $x^{2}(p)$ \\
\hline Blue light $(n=9)$ & 1 & 8 & \multirow{2}{*}{$.808(.369)$} & 1 & 8 & \multirow{2}{*}{$.808(.369)$} & 6 & 1 & \multirow{2}{*}{$2.222(.329)$} \\
\hline Stable light $(\mathrm{n}=11)$ & 3 & 8 & & 3 & 8 & & 4 & 4 & \\
\hline
\end{tabular}




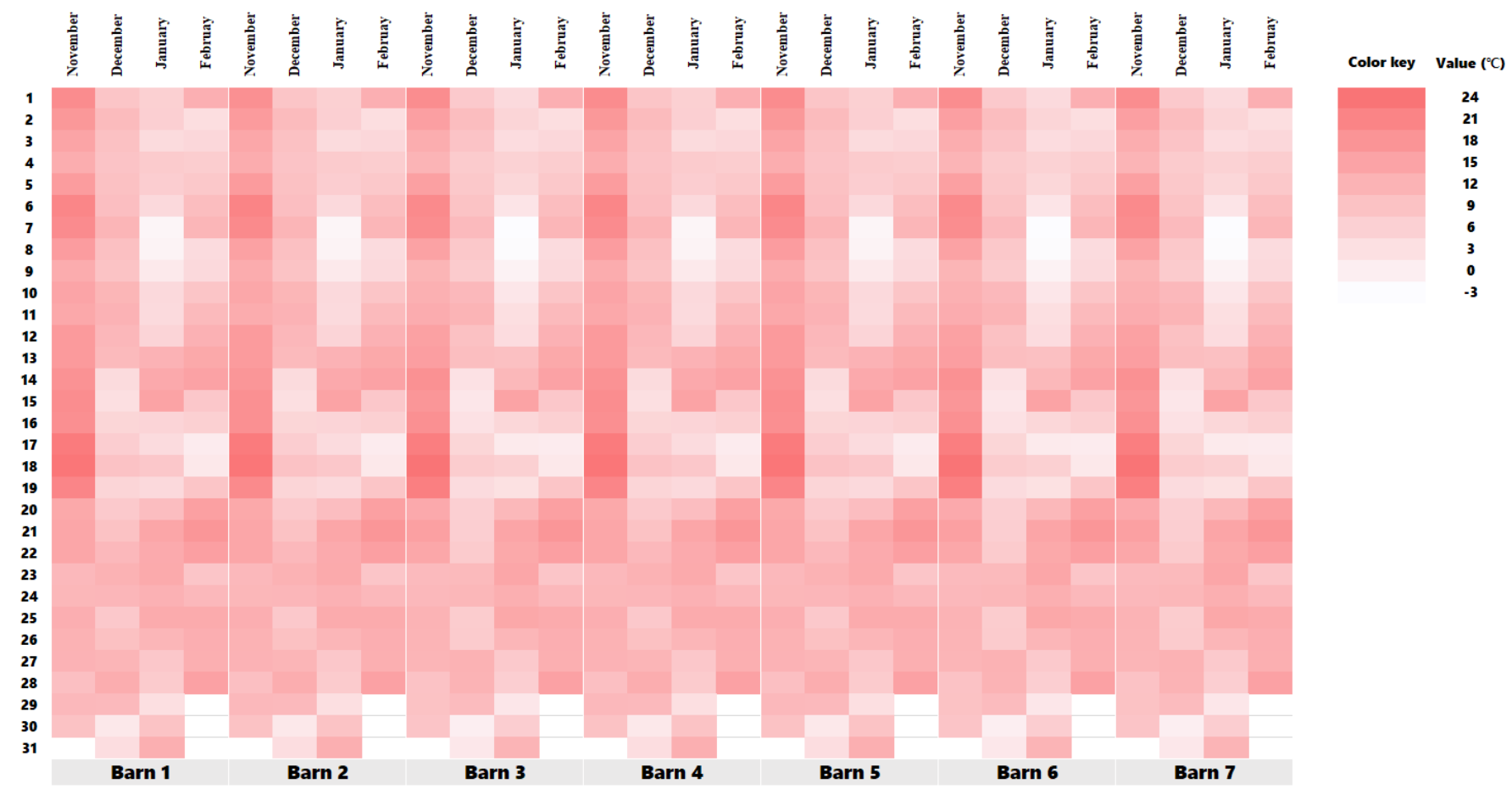

Fig. 1. Heatmap profile showing the daily mean temperature in each barn. Dark red indicates the maximum daily mean temperature and white indicates the minimum mean temperature. The values are expressed in degree celsius.

$\begin{array}{lllllllllllllllllllllllllllllll}1 & 2 & 3 & 4 & 5 & 6 & 7 & 8 & 9 & 10 & 11 & 12 & 13 & 14 & 15 & 16 & 17 & 18 & 19 & 20 & 21 & 22 & 23 & 24 & 25 & 26 & 27 & 28 & 29 & 30 & 31\end{array}$

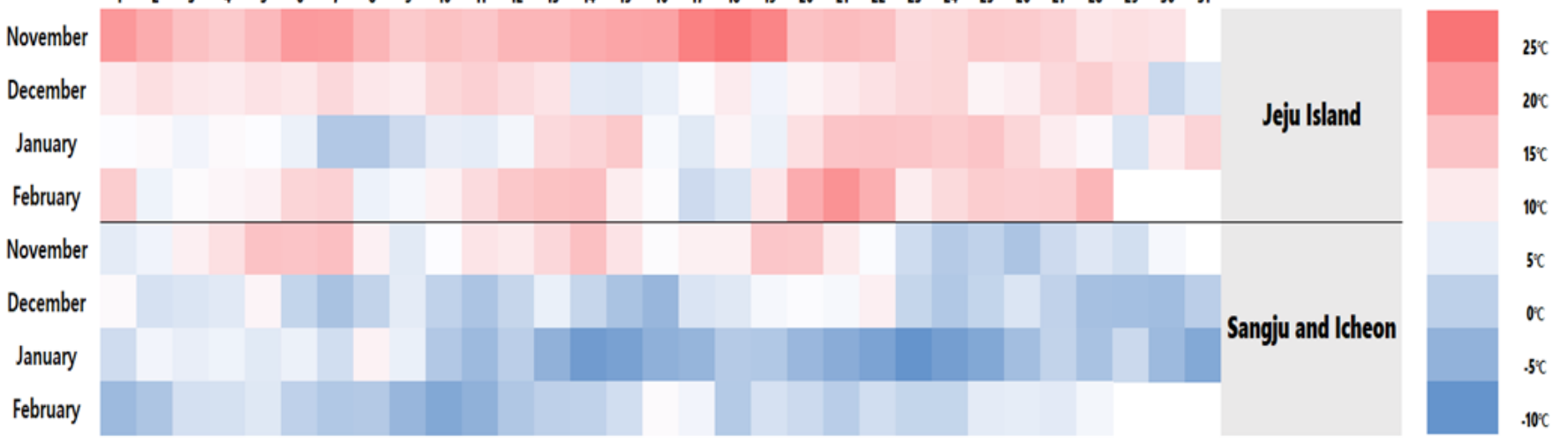

Fig. 2. Heatmap profile showing the daily mean temperature in Jeju Island and Sangju and Icheon. Dark red indicates the highest daily mean temperature and dark blue indicates the lowest mean temperature. The values are expressed in degree celsius.

One limitation of the current study is the absence of a control group of mares maintained under natural photoperiod conditions as these were not available. However, unpublished data collected by an experienced veterinarian involved in this study and who has worked within the Thoroughbred breeding industry on Jeju Island for more than twenty years suggests that the mean date of first ovulation in unlit mares occurs between late March and early April. A similar experimental design to the current study was employed previously to evaluate light therapies at advancing seasonal reproductive activity in mares.

However, our study findings were different from the previous assessment of the effect of the Equilume light masks on hastening the reproductive cycle parameters of mares [25]. Results of the 
reproductive examinations conducted in February showed that several mares exposed to blue light treatment exhibited estrus cycles and ovulation in Jeju Island, whereas none of the mares previously examined at this time exhibited ovarian activity when maintained at locations inland in Korea [25]. The BCS for the mares were not significantly different from that of the previous research, but the temperature was significantly different [29].

The role of additional external factors that can modulate the response of the mare to photoperiodic manipulation has been described in the literature. The proposed factors include ambient temperature, body condition, and quality of food [30,31]. The previous study aimed at advancing the early onset of the estrus cycle of a mare using the Equilume light mask was conducted in mainland Korea (Sangju and Icheon), and the results showed that the Equilume light mask was not effective in stimulating ovulations by February 10 [25]. It was hypothesized that the cold temperature was responsible for the failure of the effect of the Equilume light mask, as the lowest temperature was $-12.8^{\circ} \mathrm{C}$ and the mean temperature remained $0.7^{\circ} \mathrm{C}$ due to the cold weather front during the time of the experiment. Hence, the present experiment was conducted on Jeju Island, which is warmer than the mainland, and the results confirmed the effectiveness of the Equilume light mask. During the present study, the mean temperature of barns and Jeju Island were $9{ }^{\circ} \mathrm{C}$ and $9.4^{\circ} \mathrm{C}$ respectively, and the minimum temperature was also $-2.8^{\circ} \mathrm{C}$ which lasted at the most for 1-2 days during the experiment. Previous research supports that the onset of reproductive activity is closely related to the minimum and maximum environmental temperature [30]. It has also been reported that the spring transition is slowed by cold weather [32]. Therefore, the ambient temperature might have played a role as an additional external factor in advancing the resumption of estrus cycle in mares. Several studies have attributed a role to BCS, quality of feed in the regulation of reproductive efficiency. Good BCS was found to have a positive effect on the early onset of the mare's breeding season [33]. Mares with a poor body condition score of $<5$ have a longer interval to first ovulation than mares with better body condition [6]. Moreover, BCS is closely related to nutrition, as the quality of feed may advance the onset of the mare's cycle activity [31]. Another study reported on the advanced onset of the breeding season in mares provided with supplemental feed while grazing [34]. In this study, supplemental feed was provided to all mares during grazing in the pasture. Therefore, based on these studies, mares in the blue light group and the stable light group maintained a BCS of $\geq 5$, indicating that the quality of the feed was sufficient and the body condition was ideal for the reproductive cycle.

\section{CONCLUSION}

Equilume light masks can be an effective approach to induce the early seasonal estrus cycle of Thoroughbred mares in Jeju Island, Korea. Their use also enhances the efficiency of farm management by reducing labor and providing improved animal welfare by permitting the outdoor maintenance of mares in groups so that natural behaviors can be expressed.

\section{REFERENCES}

1. Nagy P, Guillaume D, Daels P. Seasonality in mares. Anim Reprod Sci. 2000;60:245-62. https://doi.org/10.1016/S0378-4320(00)00133-0

2. McKinnon AO, Squires EL, Vaala WE, Varner DD. Equine reproduction. 2nd ed. London: Wiley-Blackwell; 2011.

3. Driancourt MA, Prunier A, Palmer E, Mariana JC. Seasonal effects on ovarian follicular development in pony mares. Reprod Nutr Dev. 1983;23:207-15. https://doi.org/10.1051/ 
rnd:19830205

4. Hart PJ, Squires EL, Imel KJ, Nett TM. Seasonal variation in hypothalamic content of gonadotropin-releasing hormone $(\mathrm{GnRH})$, pituitary receptors for $\mathrm{GnRH}$, and pituitary content of luteinizing hormone and follicle-stimulating hormone in the mare. Biol Reprod. 1984;30:1055-62. https://doi.org/10.1095/biolreprod30.5.1055

5. Gentry LR, Thompson DL Jr, Gentry GT Jr, Davis KA, Godke RA, Cartmill JA. The relationship between body condition, leptin, and reproductive and hormonal characteristics of mares during the seasonal anovulatory period. J Anim Sci. 2002;80:2695-703. https://doi. org/10.1093/ansci/80.10.2695

6. Ball BA. An update on reproductive physiology of the mare. Ippologia. 2005;16:23-9.

7. Ginther OJ. Reproductive seasonality and regulation of LH and FSH in pony mares. In: Hawk HW, editor. Animal reproduction: invited papers. Montclair, NJ: Allanheld Osmun; 1979. p. 291-305.

8. Dini P, Ducheyne K, Lemahieu I, Wambacq W, Vandaele H, Daels P. Effect of environmental factors and changes in the body condition score on the onset of the breeding season in mares. Reprod Domest Anim. 2019;54:987-95. https://doi.org/10.1111/rda.13452

9. Terblanche HM, Maree L. Plasma progesterone levels in the mare during the oestrous cycle and pregnancy. J S Afr Vet Assoc. 1981;52:181-5.

10. Arendt J. Melatonin and the mammalian pineal gland. Springer Science \& Business Media; 1994.

11. Palmer E, Guillaume D. Photoperiodism in the equine species — what is a long night? Anim Reprod Sci. 1992;28:21-30. https://doi.org/10.1016/0378-4320(92)90087-T

12. Murphy BA. Circadian and circannual regulation in the horse: internal timing in an elite athlete. J Equine Vet Sci. 2019;76:14-24. https://doi.org/10.1016/j.jevs.2019.02.026

13. Cleaver BD, Grubaugh WR, Davis SD, Sheerin PC, Franklin KJ, Sharp DC. Effect of constant light exposure on circulating gonadotrophin levels and hypothalamic gonadotrophinreleasing hormone $(\mathrm{GnRH})$ content in the ovariectomized pony mare. J Reprod Fertil Suppl. 1991;44:259-66.

14. Donadeu FX, Watson ED. Seasonal changes in ovarian activity: lessons learnt from the horse. Anim Reprod Sci. 2007;100:225-42. https://doi.org/10.1016/j.anireprosci.2006.12.001

15. Langlois B, Blouin C. Effect of a horse's month of birth on its future sport performance. I. Effect on annual phenotypic indices. Ann Zootech, INRA/EDP Sci. 1997;46:393-8.

16. Langlois B, Blouin C. Effect of a horse's month of birth on its future sport performance. II. Effect on annual earnings and annual earnings per start. Ann Zootech. 1998;47:67-74.

17. Daels PF. Management of spring transition. In: Proceedings of the 8th AAEP Annual Resort Symposium; 2006; Rome, Italy.

18. Meyers-Brown GA, McCue PM, Troedsson MHT, Klein C, Zent W, Ferris RA, et al. Induction of ovulation in seasonally anestrous mares under ambient lights using recombinant equine FSH (reFSH). Theriogenology. 2013;80:456-62. https://doi.org/10.1016/ j.theriogenology.2013.04.029

19. Alexander SL, Irvine CH. Control of onset of breeding season in the mare and its artificial regulation by progesterone treatment. J Reprod Fertil Suppl. 1991;44:307-18.

20. Besognet B, Hansen BS, Daels PF. Dopaminergic regulation of gonadotrophin secretion in seasonally anoestrous mares. J Reprod Fertil. 1996;108:55-61. https://doi.org/10.1530/ jrf.0.1080055

21. Besognet B, Hansen BS, Daels PF. Induction of reproductive function in anestrous mares using a dopamine antagonist. Theriogenology. 1997;47:467-80. https://doi.org/10.1016/S0093- 


\section{X(97)00005-8}

22. Squires EL, Moran DM, Farlin ME, Jasko DJ, Keefe TJ, Meyers SA, et al. Effect of dose of GnRH analog on ovulation in mares. Theriogenology. 1994;41:757-69. https://doi. org/10.1016/0093-691X(94)90185-L

23. Douglas RH, Nuti L, Ginther OJ. Induction of ovulation and multiple ovulation in seasonallyanovulatory mares with equine pituitary fractions. Theriogenology. 1974;2:133-42. https://doi. org/10.1016/0093-691X(74)90063-6

24. Walsh CM, Prendergast RL, Sheridan JT, Murphy BA. Blue light from light-emitting diodes directed at a single eye elicits a dose-dependent suppression of melatonin in horses. Vet J. 2013;196:231-5. https://doi.org/10.1016/j.tvj1.2012.09.003

25. Lee G, Jung H, Yoon M. The effect of EquiLume light masks on the timing of seasonal ovulation of Thoroughbred mares in South Korea.J Anim Reprod Biotechnol. 2020;35:171-6. https://doi.org/10.12750/JARB.35.2.171

26. Henneke DR, Potter GD, Kreider JL, Yeates BF. Relationship between condition score, physical measurements and body fat percentage in mares. Equine Vet J.1983;15:371-2. https:// doi.org/10.1111/j.2042-3306.1983.tb01826.x

27. Burkhardt J. Transition from anoestrus in the mare and the effects of artificial lighting. J Agric Sci. 1947;37:64-8. https://doi.org/10.1017/S0021859600013083

28. Murphy BA, Walsh CM, Woodward EM, Prendergast RL, Ryle JP, Fallon LH, et al. Blue light from individual light masks directed at a single eye advances the breeding season in mares. Equine Vet J.2014;46:601-5. https://doi.org/10.1111/evj.12153

29. Shabpareh V, Squires EL, Cook VM, Cole R. An alternative artificial lighting regime to hasten onset of the breeding season in mares. Equine Pract. 1992;14:24-7.

30. Guerin MV, Wang XJ. Environmental temperature has an influence on timing of the first ovulation of seasonal estrus in the mare. Theriogenology. 1994;42:1053-60. https://doi. org/10.1016/0093-691X(94)90127-5

31. Carnevale EM, Hermenet MJ, Ginther OJ. Age and pasture effects on vernal transition in mares. Theriogenology. 1997;47:1009-18. https://doi.org/10.1016/S0093-691X(97)00058-7

32. Allen WR. Endogenous hormonal control of the mare's oestrus cycle. In: The Mare and the Foal: Proceedings of the 9th Bain-Fallon Memorial Lectures; 1987; Sydney, Australia. p. 2-13.

33. Kubiak JR, Crawford BH, Squires EL, Wrigley RH, Ward GM. The influence of energy intake and percentage of body fat on the reproductive performance of nonpregnant mares. Theriogenology. 1987;28:587-98. https://doi.org/10.1016/0093-691X(87)90275-5

34. Van Niekerk CH, Van Heerden JS. Nutrition and ovarian activity of mares early in the breeding season.J S Afr Vet Med Assoc. 1972;43:355-60. 